\title{
Long-term changes in fish assemblages of the Widawka and Grabia Rivers (Poland): pattern recognition with a Kohonen artificial neural network
}

\author{
A. Kruk \\ Department of Ecology and Vertebrate Zoology, University of Łódź, 12/16 Banacha Str., 90-237 Łódź, Poland. E-mail: krunio@ biol.uni.lodz.pl
}

The stability of occurrence, abundance and dominance of fish was compared between two sampling periods, 1963-66 and 2002-04 in two lowland rivers from the Warta/Odra system (Poland): the Widawka and its tributary Grabia (95.8 and $77.3 \mathrm{~km}$ long, respectively). The Widawka system has been under strong influence of a brown coal strip mine since the 1970s. Long stretches of the upper Widawka and of its certain tributaries were changed into concrete canals, which receive daily $660000 \mathrm{~m}^{3}$ of water disposed by the strip mine. The Grabia maintained its natural character. On the basis of the abundance of fish species, the Kohonen artificial neural network almost perfectly separated fish samples collected in 1963-66 from samples collected in 2002-04, which means that: 1) the differences in ichthyofauna between these two sampling periods were more drastic than spatial differences between the severely modified Widawka and the natural Grabia, and 2) in general, ichthyofauna at the most modified sites in 1963-66 was in better condition than at the least modified sites in 2002-04. In 1963-66, the species, roach, gudgeon, bleak and dace composed together $70 \%$ of the total fish number, while in 2002-04 the same joint dominance was gained by roach, perch and stone loach. The analysis of temporal changes in the Widawka and Grabia Rivers focused on the following 3 fish groups: (1) Non-psammophilous rheophils (NPR), which are most vulnerable to human-induced modifications, which is why their decline and/or extinction are typical for unbalanced lotic ecosystems. In this study, the total dominance of NPR decreased 5 times; (2) Psammophilous rheophils (stone loach and gudgeon), which often predominate in degraded smaller streams. In this study, the dominance of stone loach increased 3 times and was highest in the most affected stretches of the Widawka River, including those that had been canalised. Gudgeon was often dominant at moderately modified sites of the Widawka; (3) Roach and perch, whose high dominance is typical for disturbed larger rivers, which was supported also in this study by the fact that both species were most dominant in 2002-04. The dominance of roach increased almost twice and was highest in the lower courses of both rivers. A significant increase in abundance was recorded for perch, whose dominance was highest in the canalised section of the Widawka. The described changes were deep enough to influence the hardly sensitive CDI, Simpson and Shannon indices, which indicated a significant increase in dominance and a decrease in diversity of fish assemblages over the last 4 decades.

Keywords: self-organizing map, river regulation, discharge alternations, rheophilic fish, migratory fish, tolerant fish

\section{Introduction}

Human-induced alternations in Europe during the $20^{\text {th }}$ century in water quality (Eklöv et al. 1998, Boët et al. 1999, Siligato \& Böhmer 2001), channel structure (Bischoff \& Wolter 2001, Jurajda et al. 2001, Slavík \& Bartoš 2001) and connectivity (Petts 1984, Nilsson et al. 2005) caused profound changes in riverine fish assemblages (Backiel 1985, Kirchhofer \& Hefti 1996, Penczak $\&$ Kruk 2000). However, reports on the modifications in riverine ichthyofauna are often of descriptive character and relate to easily recorded qualitative changes (such as extinction) or profound quantitative declines in species (Kirchhofer \& Hefti 1996, Marszał \& Przybylski 1996).
Descriptive temporal comparisons, though undoubtedly valuable, provide very general information and often are imprecise. As the lists of extinct species are usually complete, the lists of declining but still present species often comprise only the most suffering taxa. Such fragmentary information obviously does not allow one to fully understand the dynamics of changes in fish assemblages, which makes actions focused on recovering fish assemblages more difficult. This is why the knowledge on temporal changes is so valuable when it is not limited only to the presence or absence of single species but when it also relates to changes in species abundance and in the structure of fish assemblages. Unfortunately, long-term quantitative studies are quite rare because they require compara- 


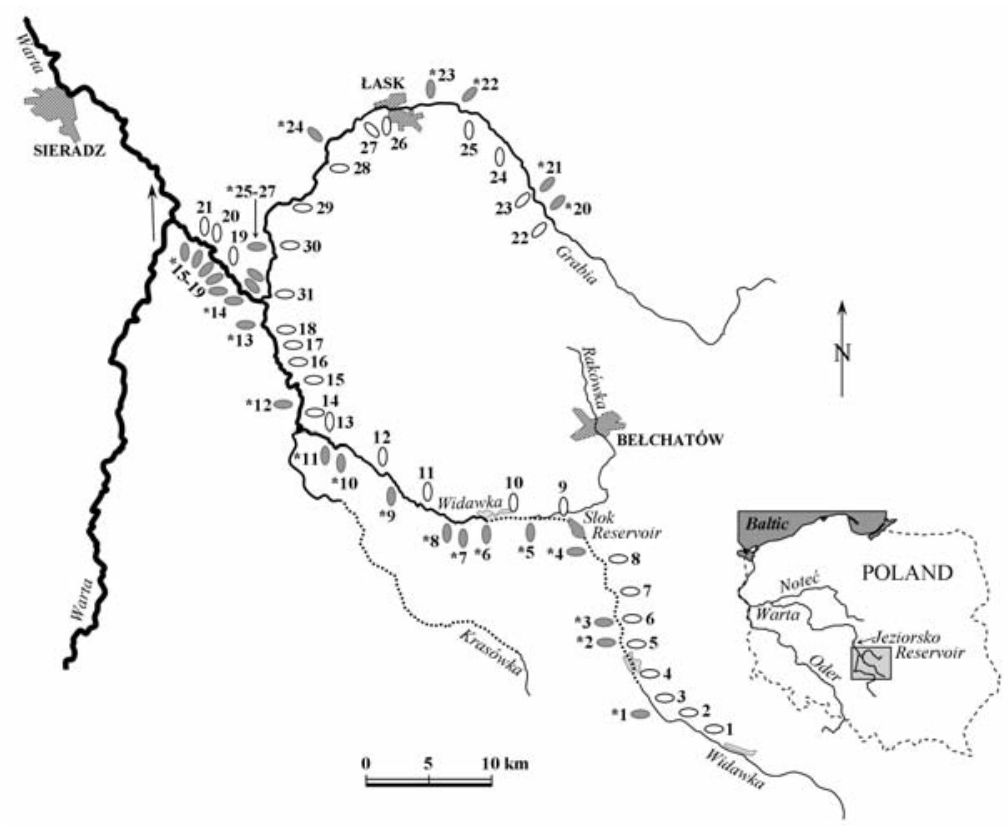

Fig. 1. Location of fish sampling sites in the Widawka and Grabia Rivers in 1963-66 (grey ellipses, symbols with an asterisk) and 2002-04 (white ellipses). The canalised sections are marked with dashed lines. Ponds are marked as dotted areas.

ble numerical data. This problem is quite common because in most countries (including Poland) complex and unified governmental monitoring systems for fish either have not been created or are very young. Data currently available, collected several decades ago by fishery cooperatives and from control catches made by anglers associations (Wiśniewolski 1987, Mastyński 1992), relate mainly to commercially or recreationally important fishes, i.e. do not include all species. This is why historical comparable numerical data on fish assemblages are inestimable as they are the only source of exact, complete and detailed information of what lived in the rivers several decades ago and how much that state differed from the present.

Such comparable numerical data were gathered in the 1960s for certain parts of the system of the upper Warta River (Penczak 1969). On the basis of those data and later fish sampling (Przybylski et al. 1993, Kruk et al. 2000) the temporal changes in the main channel of the Warta River have already been precisely described, including the extirpation of migratory and rheophilic fish, and an increase in tolerant roach and perch (Kruk et al. 2001, Kruk 2004, 2006). Nevertheless, the main river may differ from smaller rivers not only in the composition of fish fauna but also in the extent of human-induced modifications of aquatic environments (Penczak et al. 2005, Kruk et al. 2007). This is why the aim of this study is a conti- nuation of temporal ichthyological comparisons in the upper Warta system in relation to two medium-size rivers, the Widawka and the Grabia, with use of both the Kohonen artificial neural network and conventional statistical methods.

\section{Study area}

This study includes 2 rivers from the Warta/Odra system: the Widawka and the Grabia (Fig. 1). The $95.8 \mathrm{~km}$ long Widawka River is a right side tributary of the Warta River, and its drainage basin covers $2385.2 \mathrm{~km}^{2}$ (Czarnecka 1983). The Grabia River is the largest, a $77.3 \mathrm{~km}$ long tributary of the Widawka (Fig. 1). The mean slopes of both rivers amount to $1.0 \%$. The fish sampling was conducted in both rivers at 27 sites in 1963-66 (Penczak 1969) and at 31 sites in 2002-04 (Kruk et al. 2006, author's sampling) (Fig. 1). Additionally, the Widawka was sampled at 7 sites (Jakubowski et al. 1988), and the Grabia at 2 sites (Penczak \& Jakubowski 1990, Zalewski et al. 1990, Nowak \& Zalewski 1991) during the early 1980s. These studies however can be used only for descriptive comparisons, because the initial data is unavailable and thus cannot be included into numerical analyses. There are also older studies conducted between the 1930s and 1950s (Kulmatycki 1936, Köppen 1943, Pawłowski 1958, Jaskowski 
Table 1. Morphometrical characteristics of the Widawka and Grabia Rivers in 1963-66 (Penczak 1969) and $2002-04$.

\begin{tabular}{|c|c|c|c|c|c|c|c|c|}
\hline & River & $\begin{array}{l}\text { Sampling } \\
\text { sites }\end{array}$ & $\begin{array}{c}\text { Mean } \\
\text { width }[\mathrm{m}]\end{array}$ & $\begin{array}{c}\text { Mean } \\
\text { depth }[\mathrm{m}]\end{array}$ & $\begin{array}{l}\text { Dominant river } \\
\text { character }\end{array}$ & $\begin{array}{l}\text { Dominant bottom } \\
\text { substratum }\end{array}$ & Adjacent area & Remarks \\
\hline \multirow{3}{*}{ 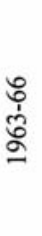 } & $\begin{array}{l}\text { Upper } \\
\text { Widawka }\end{array}$ & ${ }^{*} \mathrm{Wi} 01-06$ & 9 & 0.85 & natural & sand & meadows, forests & \\
\hline & $\begin{array}{l}\text { Lower } \\
\text { Widawka }\end{array}$ & ${ }^{*} \mathrm{Wi} 07-19$ & 19 & 0.90 & natural & sand, gravel & $\begin{array}{l}\text { arable lands, } \\
\text { meadows }\end{array}$ & \\
\hline & Grabia & ${ }^{*} \mathrm{Gr} 20-27$ & 11 & 0.90 & natural & sand, mud & meadows, forests & \\
\hline \multirow{3}{*}{ 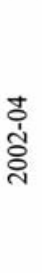 } & $\begin{array}{l}\text { Upper } \\
\text { Widawka }\end{array}$ & Wi01-10 & 6 & 0.55 & canalised & $\begin{array}{l}\text { concrete slabs, } \\
\text { sand, mud }\end{array}$ & $\begin{array}{l}\text { wasteland, meadows, } \\
\text { forests }\end{array}$ & $\begin{array}{l}\text { common filamentous } \\
\text { algae, few hidings } \\
\text { for fish }\end{array}$ \\
\hline & $\begin{array}{l}\text { Lower } \\
\text { Widawka }\end{array}$ & Wil1-21 & 17 & 1.45 & natural & sand, gravel & $\begin{array}{l}\text { arable lands, } \\
\text { wastelands }\end{array}$ & \\
\hline & Grabia & Gr22-31 & 10 & 0.65 & natural & sand, mud & $\begin{array}{l}\text { wasteland, meadows, } \\
\text { forests }\end{array}$ & \\
\hline
\end{tabular}

1962), which can serve as points of reference to a limited extent because they were based on observation, net catches of unspecified efforts, and on information gathered from fishermen and anglers.

In both sampling periods (1963-66 and 2002-04), the sites were divided into the same proportions between both rivers, i.e. about $2 / 3$ in the Widawka and $1 / 3$ in the Grabia, in order to avoid recording changes in fish resulting from different spatial allocation. Also, in both rivers, the source sections were ignored because fish assemblages in such habitats often are unstable as a result of frost penetration in winters and low water levels in hot summers (Prowse 2001, Hoffsten 2003, Matthews \& Marsh-Matthews 2003), which can lead to extreme events in fish assemblages including extinction of certain cohorts, certain species or all fish, thereby masking long-term changes.

The Widawka and Grabia Rivers are among the largest rivers in the system of the upper Warta River, which in 1986 was divided by one of the largest artificial reservoirs in Poland, the Jeziorsko Reservoir (total volume $202.8 \times 10^{6} \mathrm{~m}^{3}$, maximum surface area $42.3 \mathrm{~km}^{2}$, and maximum depth $10.5 \mathrm{~m}$ ) (Andrzejewski 1987) (Fig. 1). The dam was constructed without a fish pass and has been precluding fish migrations to any upstream parts of the system, including the Widawka and Grabia (Penczak et al. 1998a, Penczak \& Kruk 2000, Kruk \& Penczak 2003, Kruk 2004).

The studied sections of the Widawka and Grabia Rivers were morphologically similar in the 1960 s. Both rivers flowed along their natural beds, which were covered with sand and additionally with gravel in the lower Widawka, or by mud in the Grabia (Table 1). The mean depth of the rivers was about $0.9 \mathrm{~m}$, which means that the differences in stream size were realised through the channel width.

Since the mid 1970s the Widawka River has been under strong influence of the brown coal strip mine, Bełchatów, having a mining efficiency of $38 \mathrm{mln}$ tonnes of coal per year (Wachowiak 2005). In 1975, the rock mass started to be dewatered by wells, whose number nowadays amounts to about 400 (Jokiel \& Maksymiuk 1997). They have been lowering the level of ground waters by over $230 \mathrm{~m}$ protecting the excavation from flooding. However, dewatering originated a hydrological depression covering the area of $438 \mathrm{~km}^{2}$ (maximum $>600 \mathrm{~km}^{2}$ ), of which $89 \%$ is located in the Widawka drainage basin (Wachowiak 2005). The depression made water escape from streams in the $\mathrm{Wi}$ dawka system and some of them dry up (Jokiel \& Maksymiuk 1997). This is why the channel of the Widawka in its upper course was changed into a leak-proof concrete canal along a section of about $30 \mathrm{~km}$ (Fig. 1). The structural differentiation of the canal is drastically low, because it is not meandering, its banks are not covered with trees or shrubs within long distances, and it secures few hidings for fish, except for filamentous algae, which have become very abundant (Table 1). Additionally, in the canalised river section the Słok Reservoir was constructed (Fig. 1). It covers an area of 76.0 ha, and originally was used as a storage reservoir fed in $80 \%$ with mine waters, but nowadays it is used also for recreational purposes (Glinkowska \& Łukawska 2003). 
Another problem is severe pollution of the Rakówka River, a right side tributary of the Widawka (Fig. 1). The Rakówka is fishless because of a high load of sewage coming from urban areas, including the town of Bełchatów. Its water quality is mainly influenced by very low concentrations of oxygen and high amounts of nutrients (Glinkowska \& Łukawska 2003). The problem of the polluted Rakówka and its negative influence on fish was recorded also in the 1960s by Penczak (1969).

In the lower course of the Widawka, the channel width was similar as compared to the $1960 \mathrm{~s}$, but the depth increased (Table 1). This is another effect of the strip mine, which disposes on average $660000 \mathrm{~m}^{3}$ of water daily, directly or indirectly to the Widawka (Glinkowska \& Łukawska 2003). Mine waters constitute $45 \%$ of the river discharge in the outlet profile (Wachowiak 2005). Previously, mine waters were disposed upstream from the Słok Reservoir, but since 1997 most inflows through the Krasówka River, which in the 1960s was a small shallow natural stream (Kulmatycki 1936) and now is a canal (Fig. 1) almost as large in its outlet section as the Widawka.

The extent of changes in the Grabia was much smaller. The river maintained its natural character (Table 1) and was not directly modified by the mine. The reduction in channel depth (Table 1) is ambiguous because: 1) the Grabia drainage basin is located outside the hydrological depression, and 2) before the study conducted by Penczak (1969), Pawłowski (1958) recorded a similar depth as in 2002-04.

\section{Material and methods}

The study was based on 11727 specimens belonging to 31 fish species (Appendix), and collected in 1963-66 (Penczak 1969) and 2002-04 (Kruk et al. 2006, author's sampling). The recorded species were listed according to the reproductive guilds by Balon (1990) (Appendix).

Fish sampling methods adopted in 2002-04, remained the same as in 1963-66 in order to assure comparability of data sets. Single electrofishing at each site was done by two people operating anode dipnets and using full-wave rectified, pulsed $230 \mathrm{~V}$ and 3-10 A DC current from a $3 \mathrm{~kW}$ generator. The length of sites was determined in accordance with the Becklemishev's rule (Penczak 1967, 1969, Backiel \& Penczak 1989) stating that the fishing can be finished if no new species would be recorded during its continuation. In practice, fish were collected from both banks of shallow river sections $(<0.8 \mathrm{~m})$, while wading along a $100 \mathrm{~m}$ stretch, as

\section{INPUT LAYER \\ (31 NEURONS, ONE FOR EACH SPECIES)}

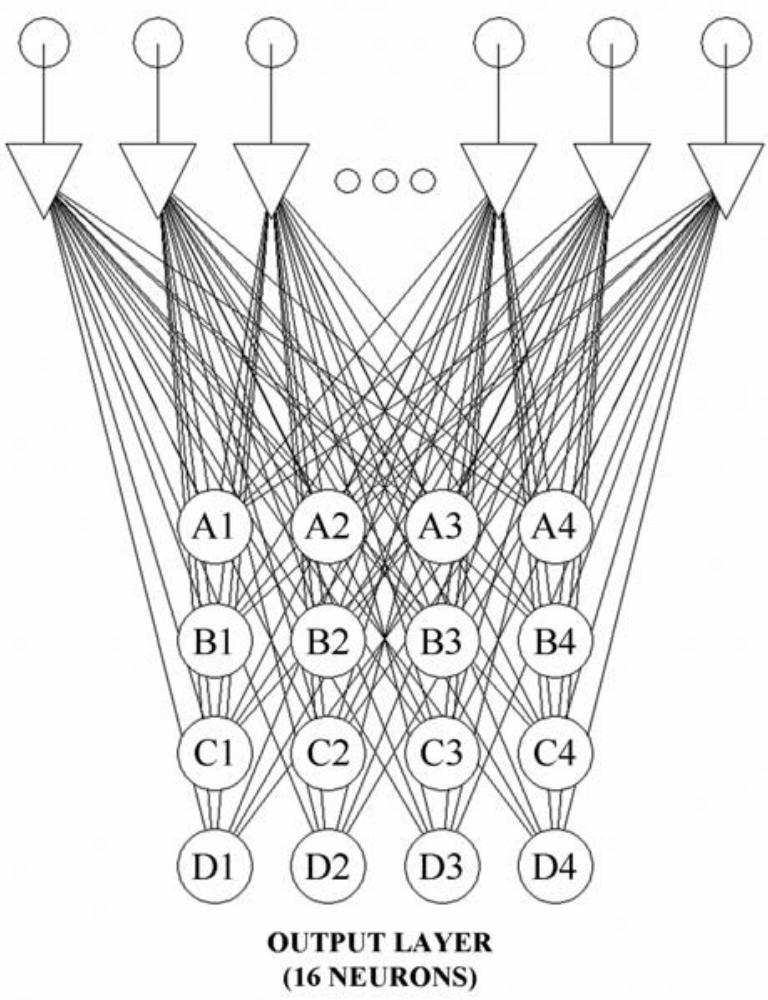

Fig. 2. The structure of the self-organizing map. Output neurons are arranged 2-dimensionally $(4 \times 4)$.

well as from a boat drifting along one bank of a $500 \mathrm{~m}$ long reach in deeper sections. Fish numbers for all sampling sites were recalculated per $500 \mathrm{~m}$ of riverbank, i.e. shallower sites were treated as if sampled along one bank along a stretch of $200 \mathrm{~m}$.

The temporal changes in fish assemblages were analysed with use of a Kohonen artificial neural network (ANN) (Kohonen 1982). Kohonen ANNs, also referred to as self-organizing maps (SOM), are widely used in ecology for data ordination (e.g. Chon et al. 1996, 2000, 2001, Lek \& Guegan 1999, 2000, Park et al. 2003a, Lek et al. 2005) because they easily deal with variables interrelated non-linearly and those with strongly skewed distributions. The latter feature of ANNs is especially useful while analysing organism counts which often exhibit distributions so strongly skewed (because of many zeroes) that no transformation will normalise them (Quinn \& Keough 2002).

SOM is built of processing units called neurons. They are arranged into two (input and output) layers (Fig. 2). The number of input neurons is the same as 


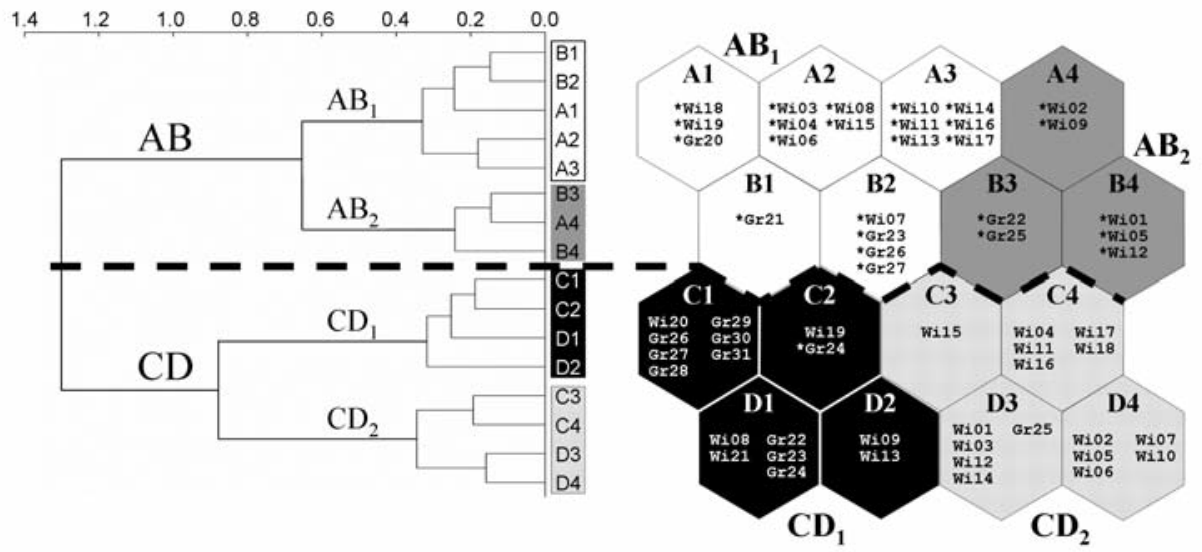

Fig. 3. Fish samples from the Widawka (Wi) and Grabia (Gr) Rivers from 1963-66 and 2002-04 assigned to output neurons. Sample symbols contain the first two letters of the river's name, followed by the number of the sampling site (the same as in Fig. 1), additionally preceded with an asterisk for samples collected in 1963-66. The clusters $A B$ and $C D$ (separated with a dashed line), and subclusters $A B_{1}, A B_{2}, C D_{l}$ and $C D_{2}$ (marked with patterns) were identified on the basis of a hierarchical cluster analysis.

the number of species. Each input neuron is connected with all the output neurons. The output neurons create a 2-dimentional topological map (in this paper, a $4 \times 4$ map selected out of many tried architectures is presented) (Fig. 2-3).

During the training procedure the dataset (31 species $\times 58$ samples, $\log$ transformed and normalised $0-1$ ) was repeatedly presented onto the input neurons and they sent signals to the output neurons. On this basis, a model of a fish sample was created for each output neuron. Models of all neurons reflected the variability in the dataset. Neighbouring neurons had similar models, while distant neurons had dissimilar models of fish samples. Each real fish sample became assigned to the output neuron whose model it resembled most. Thereby, similar samples became assigned to the same or nearby output neurons. Samples differing greatly from each other became assigned to distant neurons in terms of either the topology of the SOM (i.e. nonneighbouring) or low mutual similarity (i.e. belonging to different clusters. The cluster boundaries between the output neurons were defined with a hierarchical cluster analysis (Ward linkage, Euclidean distance). Summing up, SOM recognized the structure of the data set, distinguished classes and assigned fish samples to them.

The Kohonen artificial neural network was simulated and the hierarchical cluster analysis was done with the SOM interface for Matlab ver. 6.1.0.450. The interface allows for visualisation of each species importance over the SOM in the form of a grayness gradient.
Though the Kohonen neural network was trained with a data set containing information on all 31 species (i.e. all species influenced the assignation of fish samples to the SOM neurons), the importance planes were generated only for 22 species recorded in at least 5 samples from any sampling period. The following species were omitted: spirlin, asp, rudd, carp, sea trout, grayling, bitterling, sunbleak and stickleback (Appendix). The importance of the above sporadically caught species visualised over SOM could lead to false conclusions regarding temporal changes or differences in their spatial distribution.

Gradients over SOM were sought for the following assemblage parameters:

1. Total dominance of (a) non-psammophilous rheophils (NPR) (see Appendix), (b) psammophilous rheophils (stone loach and gudgeon), and (c) roach and perch. The NPR are most vulnerable to worsened water quality, simplified channel structure and disrupted connectivity of riverine habitats, and this is why their declines and/or extinction are typical for unbalanced lotic ecosystems (Przybylski 1993, Kirchhofer \& Hefti 1996, Oberdorff et al. 2001, Kruk \& Penczak 2003, Kruk 2004, 2006, 2007). Psammophils (stone loach and gudgeon) often predominate in degraded smaller streams (Bahlo 1991, Witkowski et al. 1991, 1992, Kruk et al. 2003, 2005), while a high dominance of roach and perch is typical for disturbed larger rivers (Przybylski 1993, Penczak et al. 1999, Kruk 2006, 2007). 
2. Community dominance index (CDI), which is the summary dominance of the two most abundant species (Krebs 1994). CDI assumes values from 0 (low dominance) to $100 \%$ (high dominance). High values of the index are typical for unbalanced assemblages.

3. Simpson index of dominance $(\lambda)$ (Odum 1980):

$$
\lambda=\sum_{i=1}^{s}\left(p_{i}\right)^{2}
$$

$p_{i}$ - proportion of individuals that i species contributes to the total in the sample,

$S$ - total number of fish species in the sample.

The Simpson index assumes values from 0 (low dominance) to 1 (high dominance). High values of the index are typical for unbalanced assemblages.

4. Shannon index of biodiversity (H') (Begon et al. 1986):

$$
H^{\prime}=-\sum_{i=1}^{s} p_{i} \log p_{i}
$$

$p_{i}$ and $S$ as above, $\log$ - common logarithm (base 10).

The Shannon index assumes values from 0 (low diversity) to $\log S$ (high diversity). Low values of the index are typical for unbalanced assemblages.

Additionally, with use of conventional statistical methods the following variables for each studied species were compared between 1963-66 and 2002-04:

1. abundance (recalculated for $500 \mathrm{~m}$ of river bank).

2. stability of occurrence (i.e. frequency in the samples).

3. dominance.

Significance of differences in any variable between sampling periods and between SOM clusters was determined with the Mann-Whitney $U$ test. Differences between SOM subclusters were assessed with the Kruskal-Wallis test, a non-parametric equivalent of ANOVA, and then post hoc comparisons were performed with the Tuckey test (Quinn \& Keough 2002).

For 6 species with marginal dominance and insignificant temporal changes in abundance (ide, bream, silver bream, tench, giebel and brown trout), only dominance and a general trend for their abundance over the studied period on SOM were presented.

Detailed data on pollution of water and morphometry of sampling sites in 1963-66 have not been kept till the present day. This is why changes in water quality and relations between fish and their environment cannot be analysed.

\section{Results}

On the basis of the cluster analysis two main clusters were distinguished: $A B$ (neurons $A 1-B 4$ ) and $C D$ (neurons $C 1-D 4$ ) (Fig. 3). Cluster $A B$ contains the fish samples collected exclusively in 1963-66. Cluster $C D$ contains all samples collected in 2002-04, and additionally one sample ( $\left.{ }^{*} \mathrm{Gr} 24\right)$ collected in the 1960 s. Thus, just on the basis of fish number, the artificial neural network very efficiently separated samples collected in 1963-66 from samples collected in 2002-04. Such a clear vertical grouping results from deep differences between these two sampling periods in the structure of fish assemblages and thus testifies to profound changes that took place over the last 4 decades. Deep modifications within the ichthyofauna are also confirmed both by species importance over SOM (Fig. 4), and by the conventional analyses.

The most suffering taxa were migratory and/or NPR species. In 2002-04 no specimens of diadromous eel and vimba, and potamodromous nase were caught (Fig. 4-5, Table 2-3). Alhough in the 1960s the dominance for each was $<1 \%$, their stability of occurrence was fairly high, amounting to $19-41 \%$ (Table 2-3). Decreases in abundance, reaching even 1 order of magnitude, were recorded also for the remaining NPR species: burbot, barbel, chub and dace, of which only the change in barbel was insignificant (Fig. 4-5). For all of them, the stability of occurrence dropped 1.7-2.7 times (Table 2). The dominance of each decreased several times (Table 3). The abundance, stability of occurrence and dominance of the psammophilous gudgeon also significantly decreased. The only rheophil whose populations increased was the psammophilous stone loach (Fig. 4, 6). Its stability of occurrence increased by half as much (Table 2), while dominance increased 3.4 times (Table 3 ).

Significant decreases were recorded also for bleak and brown bullhead (Fig. 4-6). Their stability of occurrence was reduced over 10 and 3 times (Table 2), while dominance over 92 and 15 times, respectively (Table 3 ). The marginal dominance of bream and silver bream decreased (Table 3) because of insignificant decreases in their abundance (Fig. 4). Out of the above declining species, gudgeon, bleak and dace in 1963-66 codominated with roach (Table 3 ).

Roach and pike did not show significant differences over the studied period (Fig. 4, 6). Nevertheless, even relatively small changes in the abundance of a domi- 

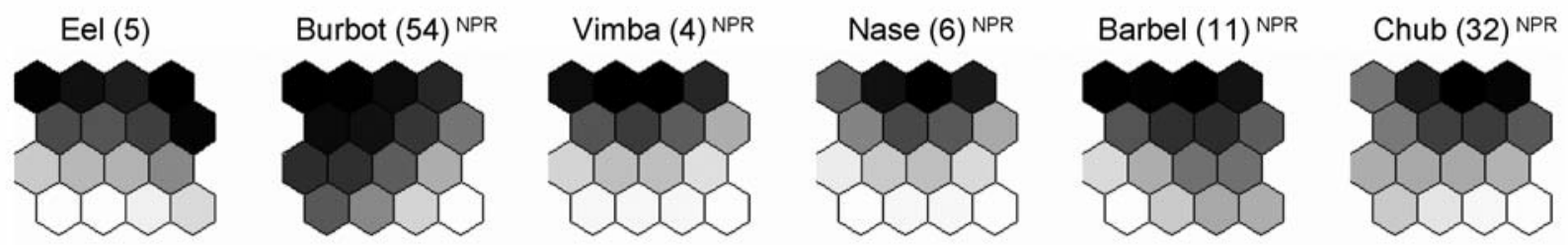
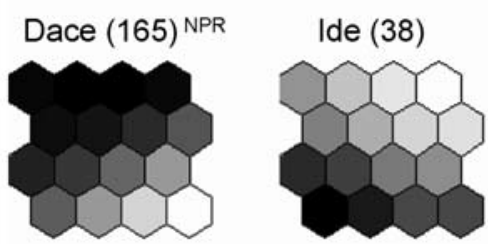

Ruffe (8)
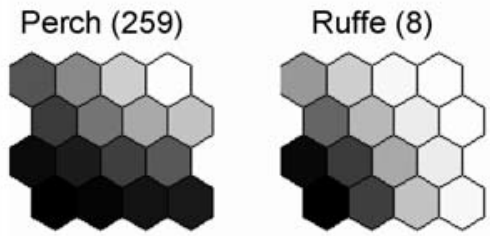

Stone loach (505) PR Gudgeon (200) PR
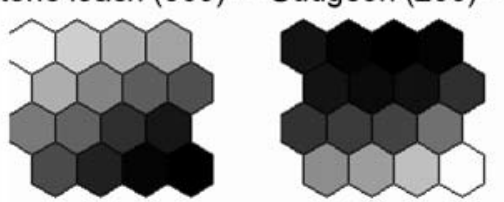

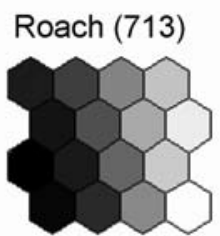

Pike (73)
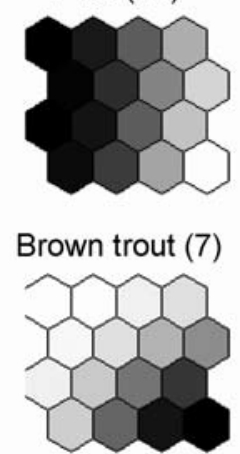

Bleak (129)

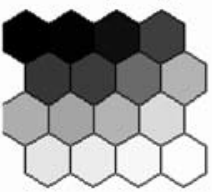

Tench (33)

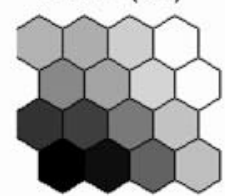

Brown bullhead (82)

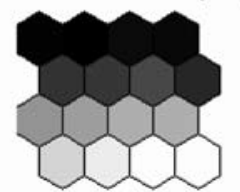

Bream (13)

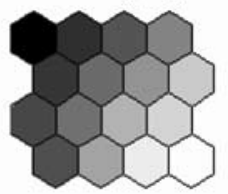

Silver bream (10)

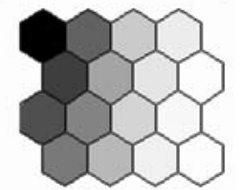

Giebel (14)

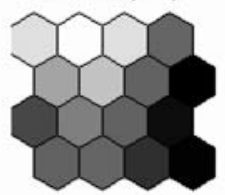

Spined loach (107)

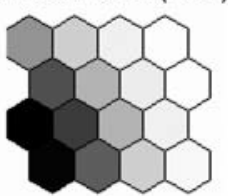

Fig. 4. Importance of fish species in 1963-66 (upper cluster $A B$ ) and 2002-04 (lower cluster $C D$ ) (compare to Fig. 3). Only species recorded in at least 5 samples from any sampling period are presented. Darker shading indicates higher abundance (scaled independently for each species: from zero to the number of specimens per $500 \mathrm{~m}$ of river bank presented in brackets). Profound temporal changes are manifested in a clear vertical gradient over SOM. Species exhibiting a horizontal gradient were similarly abundant in both sampling periods. Species with the same pattern over SOM have similar habitat preferences. NPR - non-psammophilous rheophils, PR - psammophilous rheophils.

nant may considerably influence the structure of a fish assemblage. The insignificant increase in the population of roach accompanied by a decline in many other species, led to its nearly a twice as high dominance (Table 3). The dominance of pike remained at a similar level (Table 3 ). The stability of occurrence of roach and pike slightly decreased, but remained fairly high (> 90\%) (Table 2).

A significant increase in abundance was recorded for perch, ruffe and spined loach (Fig. 4, 6). Their dominance increased by 1 order of magnitude (Table 3 ). The stability of occurrence for perch increased by $1 / 5$, ruffe over 10 times, and spined loach more than doubled (Table 2). Insignificant increases in abundance were recorded for ide, tench, giebel and for brown trout, which was absent in the 1960s (Fig. 4). The dominance of the 3 former species in the $1960 \mathrm{~s}$ was about $0.2 \%$ and increased several times over the last 4 decades (Table 3 ).
The structure of fish assemblages underwent profound modifications because of the above described changes in abundance. Between 2002-04, roach was still dominant, yet its dominance was much higher than in the 1960s (Table 3). In 1963-66, roach, gudgeon, bleak and dace composed together $70 \%$ of the total fish number, while in 2002-04, the same joint dominance was gained by roach, perch and stone loach (Table 3 ).

Moreover, in 2002-04, the dominance of the NPR fish was 5 times lower as compared to the 1960s (Fig. 7), although the number of such species increased from 10 to 11 (Table 3 ). The joint dominance of roach and perch, i.e. the first two dominants in 2002-04, more than doubled, while the total dominance of psammophils, which were the next two most numerous species in 2002-04, remained at a similar level as compared to 1963-66 (Fig. 7, Table 3). The described changes were deep enough to influence the hardly sensitive CDI, 

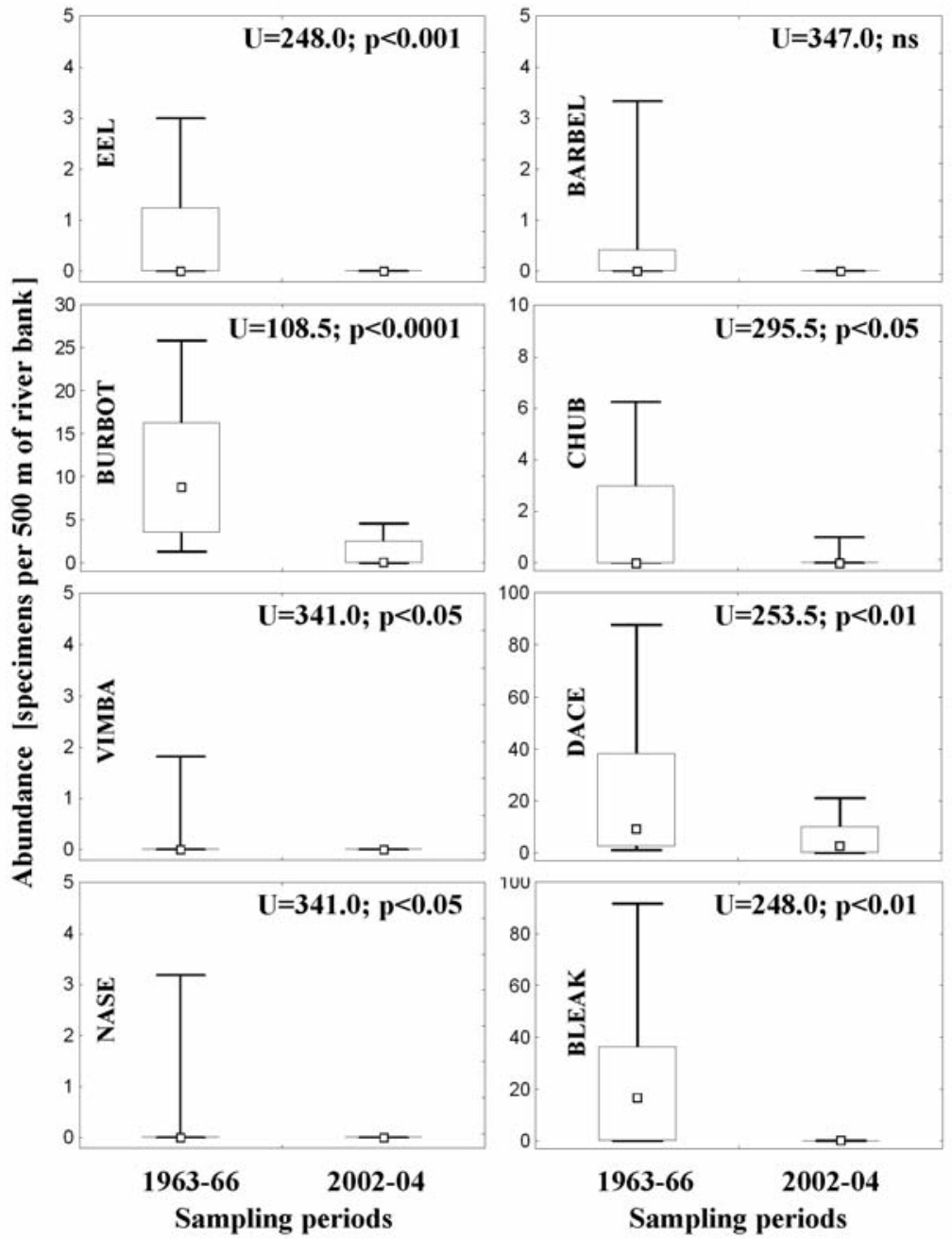

Fig. 5. Abundance of selected fish species in 1963-66 and 2002-04 in the Widawka and Grabia Rivers (presented together). Point - median, box - interquartile range, whiskers -10 th and 90th percentiles. The significance of changes was determined with the Mann-Whitney $U$ test.

Simpson and Shannon indices, which indicated a significant increase in dominance and a decrease in the diversity of fish assemblages over the last four decades (Fig. 7).

Except for the clear vertical gradient over SOM corresponding with temporal changes in the ichthyofauna, the fish samples exhibited a slight horizontal gradient, connected with the pairs of subclusters $A B_{1}, A B_{2}$ and $C D_{1}, C D_{2}$, distinguished within the clusters $A B$ and $C D$, respectively (Fig. 3). The subcluster $A B_{1}$ was characterized by higher species richness because it contai- ned samples with ide, bream, silver bream, ruffe, rudd, tench, carp and 5 lithophils: vimba, spirlin, asp, nase and barbel, which were absent in $A B_{2}$ (Table 4). The only species present in $A B_{2}$ and absent in $A B_{1}$ were giebel and bitterling. Moreover, the joint dominance of roach and perch was insignificantly higher, while the joint dominance of stone loach and gudgeon was insignificantly lower in $A B_{1}$ as compared to $A B_{2}$ (Fig. 7, Table 4). The same principle was affirmed for $C D_{1}$ and $C D_{2}$. In $C D_{1}$ the joint dominance of roach and perch was insignificantly higher, while the dominance of stone loach and gudgeon was insignificantly lower 

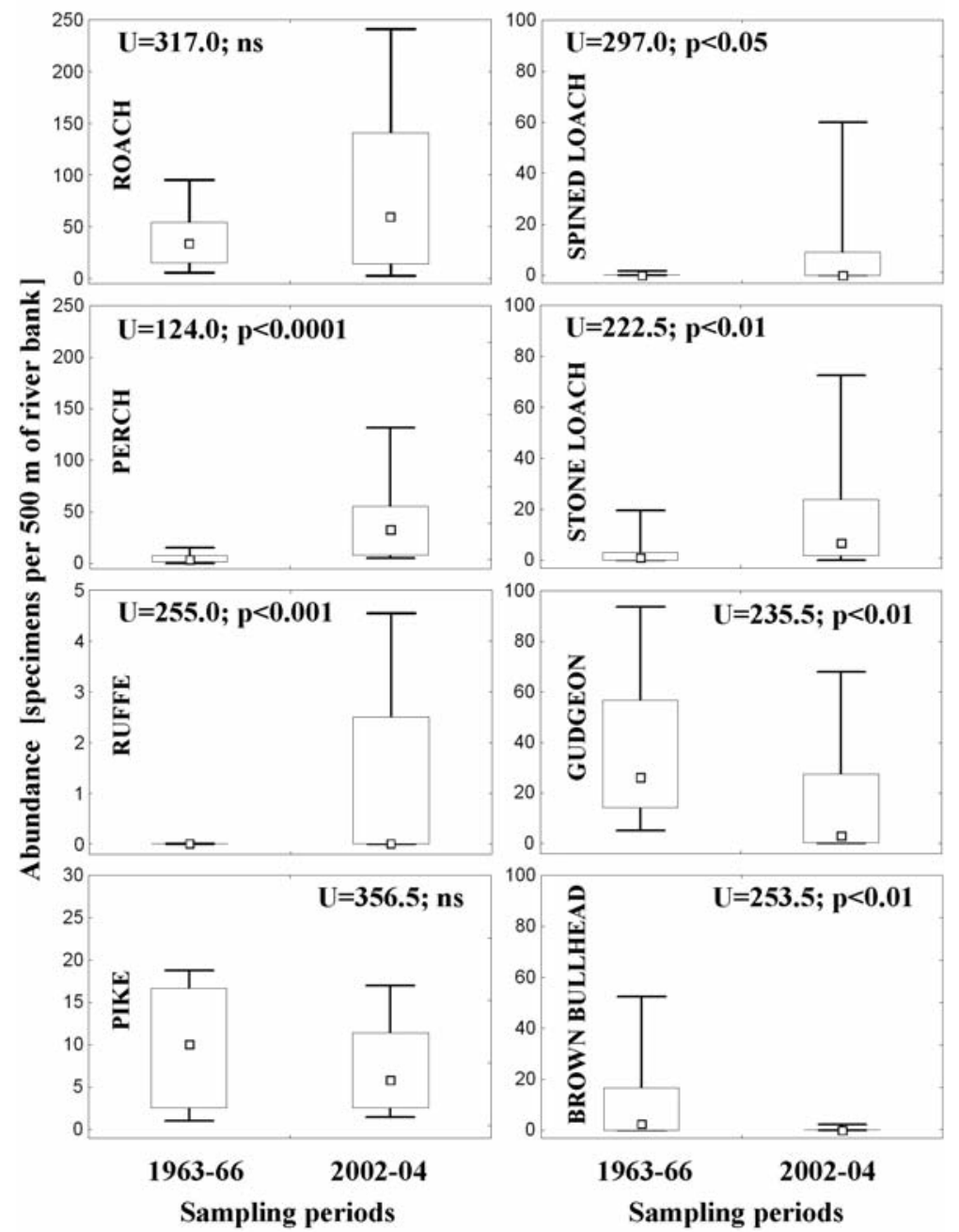

Fig. 6. Abundance of selected fish species in 1963-66 and 2002-04. Explanations as in Fig. 5.

than in $C D_{2}$ (Fig. 7, Table 4). The described importance of the dominant species was the main difference between $C D_{1}$ and $C D_{2}$ as the numbers of species exclusively present in $C D_{1}$ and $C D_{2}$ were similar (5 and 4, respectively). Additionally samples assigned to $C D_{l}$ and $\mathrm{CD}_{2}$ were of different spatial origin. Almost all samples from the Grabia and the 3 most downstream samples from the Widawka were in $C D_{1}$, while $C D_{2}$ contained mainly samples from the upper and middle course of the Widawka (Fig. 3). Samples from the canalised section of the Widawka were assigned mainly to neuron $D 4$, though two samples (Wi08 and Wi09) taken at sites neighbouring the Słok Reservoir were located in subcluster $C D_{1}$. Spatial segregation of samples in cluster $A B$ was much weaker though similar: the 6 most downstream samples from the Widawka and a majority of samples from the Grabia were present in $A B_{I}$ (Fig. $3)$. In the comparison of subclusters, the latter subcluster was the only one significantly different from $C D_{l}$, $C D_{2}$ and/or $A B_{2}$. It contained samples with higher values of the NPR dominance and the Shannon index, and with lower values of the CDI and the Simpson indices (Fig. 7). 
Table 2. Stability of occurrence of selected fish species in 1963-66 (Penczak 1969) and 2002-04.

\begin{tabular}{|c|c|c|c|c|}
\hline \multirow{2}{*}{ Species } & \multicolumn{2}{|c|}{ Stability of occurrence [\%] } & \multirow{2}{*}{$\begin{array}{l}\text { Statistics } \\
\text { of the G test }\end{array}$} & \multirow{2}{*}{ Significance level } \\
\hline & $1963-66 \quad(n=27)$ & $2002-04 \quad(n=31)$ & & \\
\hline Eel & 40.7 & 0.0 & 19.845 & 0.001 \\
\hline Burbot & 100.0 & 45.2 & 27.485 & 0.001 \\
\hline Vimba & 18.5 & 0.0 & 8.191 & 0.01 \\
\hline Nase & 18.5 & 0.0 & 8.191 & 0.01 \\
\hline Barbel & 25.9 & 9.7 & 2.709 & ns \\
\hline Chub & 48.1 & 22.6 & 4.215 & 0.05 \\
\hline Dace & 92.6 & 54.8 & 11.131 & 0.001 \\
\hline Bleak & 66.7 & 6.5 & 25.522 & 0.001 \\
\hline Roach & 100.0 & 93.5 & 2.568 & ns \\
\hline Perch & 77.8 & 93.5 & 3.102 & ns \\
\hline Ruffe & 3.7 & 41.9 & 13.390 & 0.001 \\
\hline Pike & 100.0 & 90.3 & 3.901 & 0.05 \\
\hline Spined loach & 18.52 & 41.94 & 3.808 & 0.05 \\
\hline Stone loach & 55.6 & 83.9 & 5.681 & 0.05 \\
\hline Gudgeon & 96.3 & 64.5 & 10.260 & 0.01 \\
\hline Brown bullhead & 63.0 & 19.4 & 11.848 & 0.001 \\
\hline
\end{tabular}

Table 3. Dominance of fish species in the Widawka and Grabia Rivers in 1963-66 (6380 specimens) and 2002-04 (5347 specimens); dots in the dominance columns were used for marking the not recorded species; NPR-non-psammophilous rheophils, PR-psammophilous rheophils.

\begin{tabular}{|c|c|c|c|c|c|c|}
\hline \multirow{3}{*}{ No. } & \multicolumn{3}{|c|}{ Listed according to dominance in $1963-66$} & \multicolumn{3}{|c|}{ Listed according to dominance in $2002-04$} \\
\hline & \multirow{2}{*}{ Species } & \multicolumn{2}{|c|}{ Dominance [\%] } & \multirow{2}{*}{ Species } & \multicolumn{2}{|c|}{ Dominance [\%] } \\
\hline & & $1963-66$ & $2002-04$ & & $1963-66$ & $2002-04$ \\
\hline 1. & Roach & 22.76 & 42.33 & Roach & 22.76 & 42.33 \\
\hline 2. & Gudgeon $^{P R}$ & 20.60 & 9.33 & Perch & 2.65 & 16.66 \\
\hline 3. & Bleak & 13.86 & 0.15 & Stone loach ${ }^{P R}$ & 3.53 & 11.84 \\
\hline 4. & Dace ${ }^{N P R}$ & 13.68 & 5.65 & Gudgeon $^{P R}$ & 20.60 & 9.33 \\
\hline 5. & Burbot ${ }^{N P R}$ & 6.08 & 0.93 & Dace ${ }^{N P R}$ & 13.68 & 5.65 \\
\hline 6. & Brown bullhead & 6.02 & 0.39 & Spined loach & 0.42 & 4.26 \\
\hline 7. & Pike & 4.80 & 4.17 & Pike & 4.80 & 4.17 \\
\hline 8. & Stone loach ${ }^{P R}$ & 3.53 & 11.84 & Ide & 0.22 & 1.25 \\
\hline 9. & Perch & 2.65 & 16.66 & Burbot ${ }^{N P R}$ & 6.08 & 0.93 \\
\hline 10. & Chub ${ }^{\text {NPR }}$ & 1.99 & 0.37 & Tench & 0.17 & 0.52 \\
\hline 11. & Barbel $^{\text {NPR }}$ & 0.56 & 0.13 & Ruffe & 0.03 & 0.49 \\
\hline 12. & Nase ${ }^{\text {NPR }}$ & 0.49 & . & Giebel & 0.22 & 0.43 \\
\hline 13. & Spined loach & 0.42 & 4.26 & Brown bullhead & 6.02 & 0.39 \\
\hline 14. & Rudd & 0.36 & 0.02 & Chub $^{\text {NPR }}$ & 1.99 & 0.37 \\
\hline 15. & Bream & 0.34 & 0.19 & Stickleback & 0.25 & 0.34 \\
\hline 16. & Eel & 0.33 & . & Bream & 0.34 & 0.19 \\
\hline 17. & Stickleback & 0.25 & 0.34 & Brown trout ${ }^{N P R}$ & . & 0.19 \\
\hline 18. & Vimba ${ }^{\text {NPR }}$ & 0.22 & . & Bleak & 13.86 & 0.15 \\
\hline 19. & Ide & 0.22 & 1.25 & Barbel NPR & 0.56 & 0.13 \\
\hline 20. & Giebel & 0.22 & 0.43 & Silver bream & 0.20 & 0.11 \\
\hline 21. & Silver bream & 0.20 & 0.11 & Spirlin NPR & 0.03 & 0.11 \\
\hline 22. & Tench & 0.17 & 0.52 & Sunbleak & . & 0.06 \\
\hline 23. & Carp & 0.09 & . & Rudd & 0.36 & 0.02 \\
\hline 24. & Bitterling & 0.08 & 0.02 & Bitterling & 0.08 & 0.02 \\
\hline 25. & Spirlin NPR & 0.03 & 0.11 & Asp $^{N P R}$ & 0.02 & 0.02 \\
\hline 26. & Ruffe & 0.03 & 0.49 & Grayling NPR $^{\text {No }}$ & . & 0.02 \\
\hline 27. & Asp ${ }^{N P R}$ & 0.02 & 0.02 & Sea trout ${ }^{\text {NPR }}$ & . & 0.02 \\
\hline 28. & Brown trout ${ }^{N P R}$ & . & 0.19 & Nase ${ }^{N P R}$ & 0.49 & . \\
\hline 29. & Grayling NPR & . & 0.02 & Eel & 0.33 & . \\
\hline 30. & Sea trout ${ }^{\text {NPR }}$ & . & 0.02 & Vimba ${ }^{N P R}$ & 0.22 & . \\
\hline 31. & Sunbleak & & 0.06 & Carp & 0.09 & \\
\hline
\end{tabular}




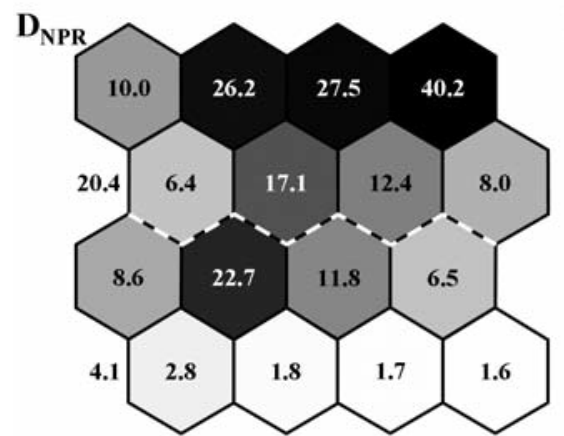

$\mathrm{U}\left(\mathrm{N}_{A B}=26, \mathrm{~N}_{C D}=32\right)=155.0 ; \mathbf{p}<\mathbf{0 . 0 0 1}$ $\mathrm{H}\left(\mathrm{N}_{A D y^{-19}}-19, \mathrm{~N}_{A D z^{-7}}-7, \mathrm{~N}_{C D y^{-16}}, \mathrm{~N}_{C D z^{-16}}=18.49 ; \mathbf{p}<\mathbf{0 . 0 0 1}\right.$ $A B_{1}[20.7] A B_{2}[20.0] C D_{1}[5.5] C D_{2}[2.7]$

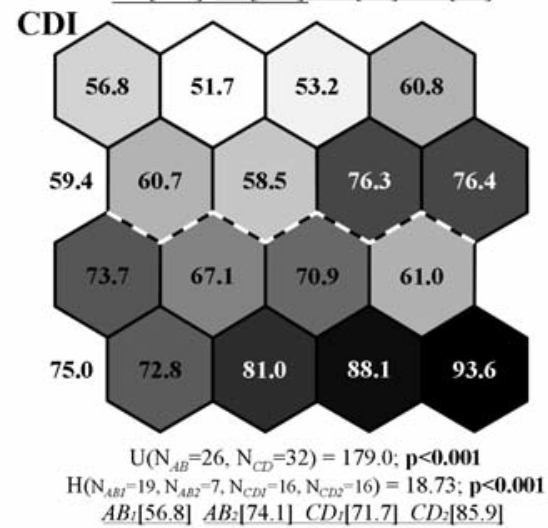

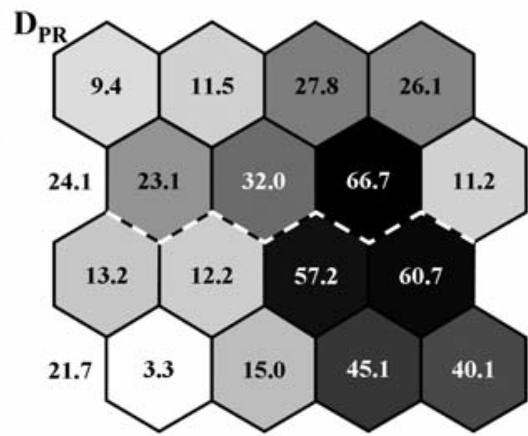

$\mathrm{U}\left(\mathrm{N}_{A B}=26, \mathrm{~N}_{C D}=32\right)=336.5 ;$ ns $\mathrm{H}\left(\mathrm{N}_{A I^{\prime}}=19, \mathrm{~N}_{A D^{\prime}}=7, \mathrm{~N}_{C D I^{\prime}}=16, \mathrm{~N}_{C D}=16\right)=6.06 ;$ ns $A B_{3}[16.2] A B_{3}[26.8] C D_{3}[7.7] C D_{2}[21.2]$

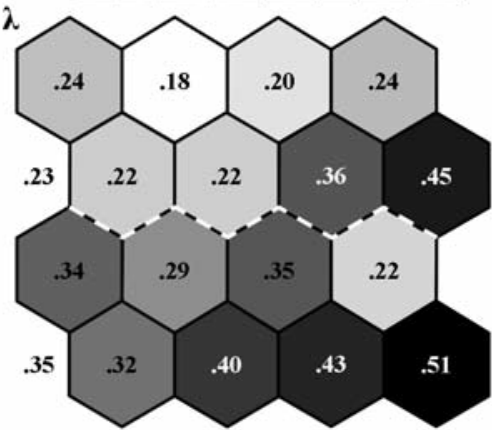

$\mathrm{U}\left(\mathrm{N}_{A B}=26, \mathrm{~N}_{C D}=32\right)=185.0 ; \mathbf{p}<\mathbf{0 . 0 0 1}$

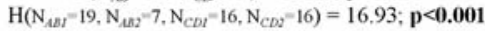
$A B_{1}[.22] A B_{2}[.30] C D_{1}[.33] C D_{2}[.40]$

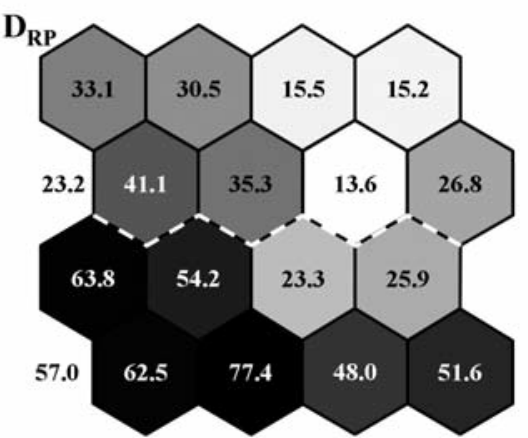

$\mathrm{U}\left(\mathrm{N}_{A B}=26, \mathrm{~N}_{C D}=32\right)=126.0 ; \mathbf{p}<\mathbf{0 . 0 0 1}$

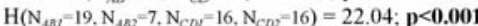
$A B_{3}[24.9] \quad A B_{3}[19.7] \quad C D_{3}[57.4] \quad C D_{3}[47.1]$

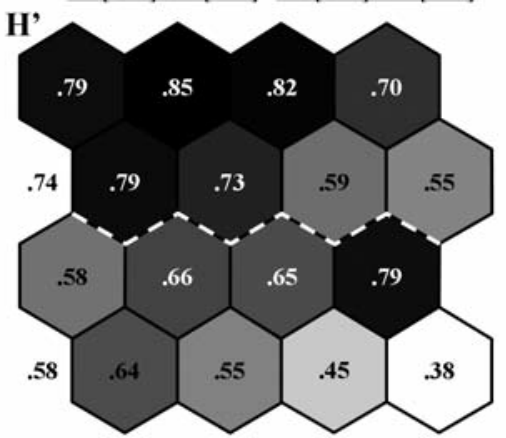

$\mathrm{U}\left(\mathrm{N}_{A B}=26, \mathrm{~N}_{C D}=32\right)=192.0 ; \mathbf{p}<\mathbf{0 . 0 0 1}$ $\mathrm{H}\left(\mathrm{N}_{A A I^{-1}}-19, \mathrm{~N}_{A B Z^{-}}-7, \mathrm{~N}_{C D I^{-16}}-16, \mathrm{~N}_{C D 2^{-1}}-16\right)=17,85 ; \mathbf{p}<0.001$ $A B_{1}[.77] \quad A B_{2}[.62] C D_{1}[.61] C D_{2}[.48]$

Fig. 7. Values of assemblage variables calculated for SOM Neurons: $\mathrm{D}_{\mathrm{NPR}}-$ total dominance of non-psammophilous rheophils [\%], $\mathrm{D}_{\mathrm{PR}}-$ dominance of psammophilous rheophils (gudgeon and stone loach) [\%], $\mathrm{D}_{\mathrm{RP}}$ - dominance of roach and perch [\%], CDI - medians of the community dominance index (i.e. the joint dominance of the 2 most dominant species) [\%], $\lambda$ - medians of the Simpson index of dominance, $H^{\prime}-$ medians of the Shannon index of biodiversity. Explanations: dashed lines show boundaries between clusters $A B$ and $C D$. Dark shading represents high values. Medians for clusters are presented on the left side of SOM. Comparisons between clusters were made with use of the Mann-Whitney $U$ test. Comparisons between subclusters were made with use of the Kruskal-Wallis test ( $H$ statistics): subclusters underlined with the same line do not differ significantly. Medians for subclusters are presented in brackets.

\section{Discussion}

The ichthyofauna of the Widawka and Grabia Rivers has undergone drastic modifications since the 1960s. Between 1963-66, rich fish assemblages existed in both rivers (Penczak 1969). The most dominant species were roach, gudgeon, bleak and dace (Table 3 ). Since that time the latter 3 species have significantly declined. The same was recorded for most migratory and/or NPR species, including vimba, nase and eel, which have probably completely died out, although single specimens were still caught in the early 1980s (Jakubowski et al. 1988, Penczak \& Jakubowski 1990, Zalewski et al. 1990). All these changes have not been stopped by stocking the Widawka and Grabia Rivers with migratory and/or NPR species, including the unrecorded nase and eel, as well as barbel and chub (Po- lish Anglers Association, unpublished data), whose dominance in 2002-04 was marginal (Table 3).

The declines of migratory and/or NPR species have been observed over the latest decades in the whole system of the Warta River (Kruk et al. 2001, Kruk 2004, Przybylski et al. 2004), as well as in other river systems in Poland (Penczak \& Kruk 2000, Marszał \& Przybylski 1996, Kukuła 2003) and all over the world (Kirchhofer \& Hefti 1996, Gomes \& Agostinho 1997, Park et al. 2003b, Agostinho et al. 2004). However, the present low dominance of those species recorded in the Widawka and Grabia is one of the highest in the system of the Warta River and may be compared only with the ichthyofauna of the upper Warta (Kruk et al. 2000, 2001, Kruk 2007) and the systems of certain tributaries of the Noteć River (Fig. 1) (Koszaliński et al. 1989, Chełkowski et al. 1996, 1997, Penczak et al. 1998b, 
Table 4. Dominance [\%] of the 31 studied fish species within SOM output subclusters and neurons. Notation "0.0" was used when a given species was recorded but its dominance was $<0.05 \%$

\begin{tabular}{|c|c|c|c|c|c|c|c|c|c|c|c|c|c|c|c|c|c|c|c|c|c|c|c|c|c|c|c|c|c|c|c|}
\hline & & \multicolumn{30}{|c|}{ Species } \\
\hline 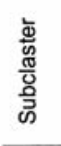 & 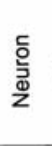 & Ш्త & 홍 & $\begin{array}{l}\text { हू } \\
\text { है }\end{array}$ & 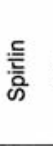 & वे & 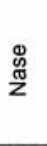 & $\begin{array}{l}\bar{\Phi} \\
\text { 迎 } \\
\text { ๓ }\end{array}$ & 疍 & : & 흐 & 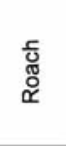 & 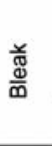 & 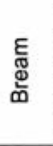 & 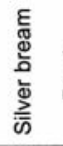 & 등 & 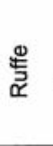 & $\stackrel{Ð}{\frac{ \pm}{0}}$ & $\begin{array}{l}\text { 흠 } \\
\vec{\alpha}\end{array}$ & 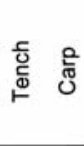 & $\begin{array}{l}\bar{\Phi} \\
\stackrel{\Phi}{0} \\
0\end{array}$ & $\begin{array}{l}\text { 유 } \\
\text { ర్త }\end{array}$ & 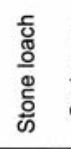 & 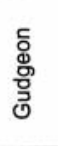 & 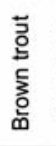 & 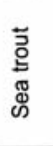 & 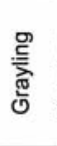 & 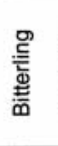 & 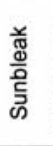 & & 怘 \\
\hline \multirow{5}{*}{$A B_{1}$} & $A 1$ & 0.6 & 6.40 & 0.2 & & & & 0.8 & 0.2 & 2.4 & 0.6 & 27.23 & 30.3 & 1.6 & 2.0 & 6.00 & 0.3 & 8.2 & 2.4 & & & & & 9.4 & & & & & & & 1.4 \\
\hline & A2 & 0.4 & 5.80 & 0.2 & & & 0.4 & 0.2 & 0.51 & 19.1 & 0.1 & 27.7 & 15.1 & & & 2.6 & & 4.7 & & $0.4 \quad 0.4$ & & & 1.01 & 10.5 & & & & & & & 10.9 \\
\hline & $A 3$ & 0.12 & 2.50 & 0.4 & 0.1 & 0.0 & 1.1 & 1.4 & 4.81 & 17.1 & 0.2 & 14.92 & 23.5 & 0.5 & 0.0 & 0.6 & & 2.2 & & 0.1 & & 0.0 & 2.22 & 25.7 & & & & & & 0.1 & 2.5 \\
\hline & $B 1$ & 0.62 & 2.9 & & & & & & & 3.5 & 0.6 & 37.4 & 2.9 & 0.6 & 1.2 & 3.5 & & 11.0 & 1.2 & & & 11.6 & & 23.0 & & & & & & & \\
\hline & $B 2$ & 0.110 & 10.5 & & & & & & 0.3 & 6.3 & 0.4 & 31.0 & 6.0 & 0.2 & & 4.2 & & 6.5 & & 0.3 & & 0.2 & 8.32 & 23.7 & & & & & & & 2.0 \\
\hline \multirow{3}{*}{$A B_{2}$} & $A 4$ & 0.9 & 8.0 & & & & & & 0.33 & 32.0 & & 14.9 & 5.7 & & & 0.3 & & 1.7 & & & & & 0.82 & 25.2 & & & & & & & 10.2 \\
\hline & B3 & & 8.4 & & & & & & & 4.0 & & 10.4 & & & & 3.2 & & 5.2 & & & & 0.71 & 14.85 & 51.9 & & & & 1.2 & & & 0.2 \\
\hline & $B 4$ & 2.2 & 1.4 & & & & & & 4.0 & 2.5 & & 26.1 & & & & 0.7 & & 2.9 & & & 5.1 & & 1.4 & 9.8 & & & & & & 5.43 & 38.5 \\
\hline \multirow{4}{*}{$C D_{1}$} & $C 1$ & & 1.0 & & & & & & 0.3 & 7.3 & 0.6 & 53.6 & 0.2 & 0.1 & 0.11 & 10.2 & 0.4 & 4.7 & & 0.1 & 0.2 & 7.3 & 3.11 & 10.1 & & & & 0.0 & & & 0.7 \\
\hline & $C 2$ & & 8.5 & & & & & & 0.2 & 14.0 & 0.2 & 47.2 & & & 0.2 & 7.2 & 0.2 & 7.7 & 2.2 & & & 0.2 & 0.71 & 11.5 & & & & & & & \\
\hline & D1 & & 1.5 & & & & & & 0.2 & 1.1 & 4.6 & 33.4 & & 1.0 & 0.12 & 29.0 & 1.6 & 5.2 & 0.2 & 3.5 & & 15.0 & 2.9 & 0.4 & & & & & 0.3 & & \\
\hline & $D 2$ & & & & 1.1 & & & & & 0.4 & 0.7 & 31.0 & & & & 46.3 & 0.7 & 2.0 & & 1.1 & 0.4 & 0.51 & 12.1 & 2.9 & 0.2 & 0.2 & & & & & 0.4 \\
\hline \multirow{4}{*}{$C D_{2}$} & C3 & & 4.9 & & & & & 2.0 & & 4.9 & & 14.6 & & & & 8.7 & 0.9 & 5.8 & & & & & & 56.4 & & & & & & 0.9 & \\
\hline & $C 4$ & & 0.3 & & & 0.1 & & 0.5 & 0.6 & 4.4 & 0.2 & 22.9 & 0.2 & 0.4 & & 3.0 & & 1.9 & & 0.1 & 1.7 & & 20.44 & 40.4 & 0.4 & & 0.1 & & & 2.3 & 0.1 \\
\hline & D3 & & 0.1 & & & & & & 0.1 & 0.9 & 0.5 & 33.5 & & & & 14.5 & & 3.0 & & 0.7 & & & 42.4 & 2.8 & 0.5 & & & & 0.2 & 0.1 & \\
\hline & $D 4$ & & & & & & & & & & 4.5 & 6.0 & & & & 45.5 & & 1.0 & & & 1.3 & & 40.1 & & 1.6 & & & & & & \\
\hline
\end{tabular}

Dębowski et al. 2000). The fact that fish assemblages of the Widawka and Grabia Rivers, despite their profound modifications, belong to the best preserved in the whole system of the Warta, clearly shows how strongly other parts of the system must have been impacted by humans (however, no long-term comparisons are available for them).

The population parameters for 2 psammophilous rheophils: stone loach and gudgeon were analysed apart from other rheophils, because these 2 species often predominate in degraded smaller streams (Bahlo 1991, Witkowski et al. 1991, Kruk et al. 2003, 2005). A confirmation of this observation is also provided in this study in their higher joint dominance in subcluster $C D_{2}$ (Fig. 7), containing samples from the most modified sites (Fig. 3). Stone loach especially prefers shallow habitats with elevated water velocities (Lamouroux et al. 1999, Copp \& Vilizzi 2004). On the one hand, laboratory experiments show that it hardly tolerates severe pollution (Clark \& Fraser 1983), but on the other hand it is a first dominant in polluted streams (Siligato \& Böhmer 2001). In general, it prefers coarser substrates (Welton et al. 1991, Mastrorillo \& Dauba 1999, Fischer 2000), but is highly adaptable in this respect (Fischer 2000). Even in canalised and lacking natural in-channel shelter streams, stone loach may be very abundant
(Brunken 1989, Siligato \& Böhmer 2001), as they can hide in gaps between concrete slabs (Kruk et al. 2003). In fact, such structurally simplified habitats with fairly clean and fast flowing water were created when the upper Widawka was transformed into a concrete canal and when it was fed with large amounts of water by the strip mine (Glinkowska \& Łukawska 2003). Indeed, the highest dominance of stone loach (even $>40 \%)$ was recorded in the upper and middle Widawka (subcluster $C D_{2}$ including neuron $D 4$ with samples from canalised sites) (Fig. 3, 4, Table 4). The decline of gudgeon in long-term studies was recorded not only in the Widawka and Grabia (Fig. 6) but also in the upper Warta River (Kruk et al. 2001). Like stone loach, gudgeon also reacts in a different way to human pressure; on the one hand it was absent in the severely polluted stretches of the Warta (Penczak 1969, Przybylski 1993, Kruk 2007), but on the other hand it co-dominated with roach and/or perch in some navigated European canals (Pygott et al. 1990, Wolter 2001). In comparative studies, stone loach is regarded as more tolerant than gudgeon with respect to both water quality and other features of habitats (Verneaux 1981, Grandmottet 1983) and this is why profound changes of the environmental quality, especially in the Widawka, favoured stone loach and caused gudgeon to decline. The increase in 
stone loach could additionally intensify the decline in gudgeon as food niches of both species overlap to a large extent (Przybylski \& Bańbura 1989, Jansen et al. 1996). The latter two statements are congruent with the state recorded between 2002-04 when gudgeon was dominant at several sites located mainly in the middle course of the Widawka (neurons $C 3$ and $C 4$ ), and was absent or almost absent at sites where the dominance of stone loach was highest (neurons D3 and D4) (Table 4).

Since the 1960s the dominance of roach has increased twice, and perch became a new co-dominant (Fig. 4 , Table 3). Roach is a generalist (Schiemer \& Wieser 1992), often recorded in high abundance in stretches extremely different in environmental quality (Przybylski 1993, Wolter \& Vilcinskas 1997, Irz et al. 2006, Kruk 2007). It has been proven that in heavily polluted water, roach not only can survive but can also increase its production (Verneaux 1981, Clark \& Fraser 1983). In the degraded middle course of the Warta River, the increase in roach biomass was however realized not by higher body mass, but by an increased number of specimens (Kruk, unpublished data) attaining smaller body sizes (Przybylski 1996). In the Warta River, a long-term increase in dominance was also recorded for perch (Kruk 2006), whose strong increase can be favoured by channel engineering (Wolter \& Vilcinskas 1997 , Penczak \& Kruk 2005). This is clearly supported by this study, because the highest dominance $(>45 \%)$ of perch was recorded in neurons $D 2$ and $D 4$ containing samples collected in 2002-04 from the canalised section of the Widawka, while in 1963-66 the dominance of this species was several times lower (Fig. 3, Tables 3,4). Perch and roach are two first dominants not only in the Widawka and Grabia, but also in other human-impacted parts of the Warta River system (Penczak et al. 1999, Penczak \& Kruk 2005, Kruk 2007) and of other lowland systems in Poland (Penczak et al. 2005, Kruk et al. 2007).

There are several reasons for the recorded temporal changes. First, transforming long fragments of the upper Widawka into a concrete canal of reduced dimensions (Table 1) resulted in a drastic structural simplification of habitats. Those fragments of the river were devoid of meanders and thus the diversity of water depth and current in channel cross-section became drastically reduced (Witkowski et al. 1991, Kubečka \& Vostradovský 1995, Boët et al. 1999, Kruk et al. 2003). In addition, the ecotonal zones were devastated because banks were cleared of aquatic and riparian vegetation and covered with concrete. Even in river fragments flowing through forests, trees were usually too far from the channel to allow their branches to hang over or become immersed in the water. The ecotones are responsible for the reduction of agricultural run off. They also serve for fish as foraging areas and provide shelter against predators (Zalewski et al. 1995, Penczak 2001, Wang et al. 2001, Penczak et al. 2006). The availability of spawning and nursery grounds has been reduced because neighbouring areas are not flooded in spring (Bayley 1995, Kubečka \& Vostradovský 1995, Ligon et al. 1995, Jurajda et al. 2001). The artificial canal of the upper Widawka lacks any connection with oxbow lakes, which also may serve as spawning grounds, and are used by fish as winter refugia (Witkowski 1986, Penczak et al. 2000, 2003a, b). In remaining seasons these habitats of stagnating water are preferred by limnophilic and many eurytopic fish, which in the upper Widawka may suffer especially from elevated water speed, caused by higher than natural volumes of water disposed by the strip mine (Table 1).

Another problem is the limited connectivity in the Widawka system resulting from several small impoundments lacking fish passes. They split the system into smaller parts, between which only downstream migrations are possible. The negative consequences of such discontinuity become larger with decreasing stream size. In small streams, the environmental conditions are less stable. Especially frost penetration in winter, draughts in hot summers or episodes of severe water pollution or intensified engineering works increase the risk of fish extirpation (Prowse 2001, Hoffsten 2003, Matthews \& Marsh-Matthews 2003). The natural mechanism of compensating these losses is recolonisation from downstream river fragments, where larger volumes of water form a more stable environment. This mechanism however does not work in the Widawka system. Additionally, the whole upper Warta system is separated from the rest of the Odra system by the dam of the Jeziorsko Reservoir (no fish pass either) (Penczak et al. 1998a) and by the chemical barrier of the severely polluted middle course of the Warta (Przybylski 1993, Kruk 2007); both led to a decline in potamodromous barbel in the upper Warta (Przybylski et al. 2004), and probably total extinction of natural populations of the critically endangered potamodromous nase, anadromous vimba and catadromous eel (Kruk 2004).

The next important aspect are undesirable long-term changes to fish communities in the upper Warta, including declines in NPR fish and in the above mentioned migratory fish, as well as an increased dominance of roach and perch (Kruk et al. 2001, Kruk 2006), thus resembling the changes in ichthyofauna of the Widawka and Grabia Rivers. Even if fish migrations were possi- 
ble in the two latter rivers, the Warta could serve as a potential source of colonists belonging to vulnerable species to a limited extent.

The cumulative effect of the above mentioned factors made the temporal (vertical) gradient predominate over the spatial (horizontal) gradient (Fig. 3), i.e. the samples were grouped first by the period of collection and then by area of collection. This means that in general the most modified sites in 1963-66 had ichthyofauna in better condition than the least modified sites in 2002-04 (despite insignificant differences between subclusters $A B_{2}$ and $C D_{1}, C D_{2}$ in certain variables). This result shows how much has to be done in order to achieve an ecologically satisfactory status of the ichthyofauna in the studied rivers.

\section{Acknowledgements}

I am very grateful to Professors Sovan Lek, Young-Seuk Park and Ryszard Tadeusiewicz, who were my teachers of ANNs. I thank Professor Tadeusz Penczak for the possibility of utilising his initial fish sampling data and for helpful comments on the manuscript. I express my appreciation to Henryk Koszaliński, Dr Grzegorz Zięba, Dr Lidia Marszał, Dr Joanna Grabowska, Szymon Tybulczuk and Piotr Spychalski for their participation in fieldwork, and to Dr Łukasz Głowacki and American Journal Experts for revising the English. The study was supported by the Ministry of Science and Higher Education (grant 3 P04F 009 22).

\section{References}

Agostinho A.A., Gomes L.C., Veríssimo S. \& Okada E.K. 2004. Flood regime, dam regulation and fish in the Upper Paraná River: effects on assemblages attributes, reproduction and recruitment. Rev. Fish Biol. Fisheries, 14, 11-19.

Andrzejewski W. 1987. - Nowy zbiornik zaporowy na Warcie [A new dam reservoir on the Warta River]. Gosp. Ryb., 10, 17-19 (in Polish).

Backiel T. 1985. - Fall of migratory fish populations and changes in commercial fisheries in impounded rivers in Poland. Pages 28-41 in Alabaster J.S. (ed.). Habitat Modification and Freshwater Fisheries. Proceedings of a Symposium of the European Inland Fisheries Advisory Commission. Butterworths, FAO, London.

Backiel T. \& Penczak T. 1989. - The Fish and Fisheries in the Vistula River and its Tributary, the Pilica River. In Dodge D.P. (ed.). Proceedings of the International Large River Symposium. Can. Spec. Publ. Fish. Aquat. Sci., 106, 488-503.

Bahlo K. 1991. - The fish fauna of running waters in the District of Gifhorn, Lower Saxony. Braunschweiger Naturkundliche Schriften, 3, 1005-1020.

Balon E.K. 1990. - Epigenesis of an epigeneticist: the development of some alternative concepts on the early ontogeny and evolution of fishes. Guelph Ichthyol. Rev., 1, 1-48.

Bayley P.B. 1995. - Understanding large river-floodplain ecosystems. BioScience, 45, 153-158.

Begon M., Harper J.L. \& Townsend C.R. 1986. - Ecology. Individuals, Populations and Communities. Blackwell Scientific Publications, Oxford, pp. 594-595.

Bischoff A. \& Wolter C. 2001. - The 0+ fish community structure in a large lowland river: first results of a study from the River Oder. Arch. Hydrobiol. Suppl., 135, 137-151.
Boët P., Belliard J., Berrebi-dit-Thomas R. \& Tales E. 1999. Multiple human impacts by the City of Paris on fish communities in the Seine river basin, France. Hydrobiologia , 410, 59-68.

Brunken H. 1989. - Lebensraumansprüche und Verbreitungsmuster der Bachschmerle Noemacheilus barbatulus (Linnaeus, 1758). Fischökologie, 1, 29-45.

Chełkowski Z., Chełkowska B., Antoszek O. \& Gancarczyk J. 1996. - Cyclostomates and fishes of the Drawa River within the limits of the Drawieński National Park. Acta Ichthyol. Piscat., 26, 3-33.

Chełkowski Z., Chełkowska B. \& Antoszek O. 1997. - Cyclostomates and fishes of the drainage basin of the river Płociczna. Acta Ichthyol. Piscat., 27, 79-111.

Chon T.S., Park Y.S., Moon K.H. \& Cha E. 1996. - Patternizing communities by using an artificial neural network. Ecol. Modell., 90, 69-78.

Chon T.S., Park Y.S. \& Park J.H. 2000. - Determining temporal pattern of community dynamics by using unsupervised learning algorithms. Ecol. Modell., 132, 151-166.

Chon T.S., Kwak I.S., Park Y.S., Kim T.H. \& Kim Y. 2001. - Patterning and short-term predictions of benthic macroinvertebrate community dynamics by using a recurrent artificial neutral network. Ecol. Modell., 146, 181-193.

Clark E.R. \& Fraser J.A.L. 1983. - The survival and growth of six species of freshwater fish, in tapwater and diluted and undiluted effluent from sewage percolating filters. J. Fish Biol., 22, 431-445.

Copp G.H. \& Vilizzi L. 2004. - Spatial and ontogenetic variability in the microhabitat use of stream-dwelling spined loach (Cobitis taenia) and stone loach (Barbatula barbatula). J. Appl. Ichthyol., 20, 440-451.

Czarnecka H., ed. 1983. - Podziat hydrograficzny Polski. Część I. Zestawienia liczbowo-opisowe [Hydrographical Division of Poland. Part I. Numerical and descriptive specifications]. Wydawnictwo Komunikacji i Łączności, Warsaw (in Polish).

Dębowski P., Terlecki J., Gancarczyk J., Martyniak A., Kozłowski J., Wziatek B. \& Hliwa P. 2000. - The ichthyofauna of the rivers of the Drawieński National Park. Sci. Ann. Pol. Angl. Assoc., 13, 87-107 (in Polish with Engl. summ.).

Eklöv A.G., Greenberg L.A., Brönmark C., Larsson P. \& Berglund O. 1998. - Response of stream fish to improved water quality: a comparison between the 1960s and 1990s. Freshwater Biology, 40, 771-782.

Fischer P. 2000. - Test of competitive interactions for space between two benthic fish species, burbot Lota lota, and stone loach Barbatula barbatula. Environ. Biol. Fishes, 58, 439-446.

Glinkowska G. \& Łukawska U. 2003. - Komunikat o stanie czystości wód zlewni rzeki Widawki w roku 2002 [Announcement about the state of water purity in the Widawka River drainage basin in 2002]. The Voivodeship Inspection for Environmental Protection in Łódź, Sieradz (in Polish).

Gomes L.C. \& Agostinho A.A. 1997. - Influence of the flooding regime on the nutritional state and juvenile recruitment of the curimba, Prochilodus scrofa, Steindachner. Fisheries Management and Ecology, 4, 263-274.

Grandmottet J.P. 1983. - Principales exigences des téléostéens dulcicoles vis-à-vis de l'habitat aquatique. Annales Scientifiques de l'Université de Besançon, 4, 3-32.

Hoffsten P.O. 2003. - Effects of an extraordinarily harsh winter on macroinvertebrates and fish in boreal streams. Arch. Hydrobiol., 157, 505-523.

Irz P., Odion M., Argillier C. \& Pont D. 2006. - Comparison between the fish communities of lakes, reservoirs and rivers: can natural systems help define the ecological potential of reservoirs? Aquat. Sci., 68, 109-116. 
Jakubowski H., Mann R.H.K. \& Penczak T. 1988. - Changes in the ichthyofauna of the Widawka River from 1963 to 1982 . Acta Univ. Lodz., Folia limnol., 3, 67-83 (in Polish with Engl. summ.).

Jansen W., Kappus B. \& Böhmer J. 1996. - Fish diets and densities of benthos upstream and downstream of a man-made barrier on the Glems River, Baden-Württemberg, Germany. Pol. Arch. Hydrobiol., 43, 225-244.

Jaskowski J. 1962. - Materiały do znajomości ichtiofauny Warty i jej dopływów [Contribution to the knowledge of the ichthyofauna of the Warta River system]. Fragmenta Faunistica, 28, 449-499 (in Polish with Russian and German summ.).

Jokiel P. \& Maksymiuk Z. 1997. - Przeobrażenia stosunków wodnych w wyniku przyspieszonej industrializacji na przykładzie Bełchatowskiego Okręgu Przemysłowego [Changes in hydrological regime resulting from accelerated industrialization - the example of the Bełchatów Industrial District]. Geographical Journal, 68, 71-79 (in Polish with French summ.).

Jurajda P., Reichard M., Hohausová E. \& Černý J. 2001 . - Comparison of $0+$ communities between regulated-channelized and floodplain stretches of the River Morava. Arch. Hydrobiol. Suppl., 135, 187-202.

Kirchhofer A. \& Hefti D., eds 1996. - Conservation of Endangered Freshwater Fish in Europe. Birkhäuser Verlag, Basel, Switzerland.

Kohonen T. 1982. - Self-organized formation of topologically correct feature maps. Biological Cybernetics, 63, 201-208.

Köppen E. 1943. - Verzeichnis der im Naturkunde-Museum zu Litzmannstadt gesammelten, aufgestellten und beobachteten Wirbeltiere des Litzmannstädter Raumes. Oberbürgermeister der Stadt Litzmannstadt, Łódź.

Koszaliński H., Penczak T., Galicka W., Lobon-Cervia J. \& Jakucewicz H. 1989. - Ichthyofauna of the Gwda River drainage basin. Sci. Ann. Pol. Angl. Assoc., 2, 71-99 (in Polish with Engl. and Russian summ.).

Krebs C. J. 1994. - Ecology: the experimental analysis of distribution and abundance. Harper Collins, New York.

Kruk A. 2004. - Decline in migratory fish in the Warta River, Poland. Ecohydrology \& Hydrobiology, 2, 147-155.

Kruk A. 2006. - Self-organizing maps in revealing variation in nonobligatory riverine fish in long-term data. Hydrobiologia, 553, 43-57.

Kruk A. 2007. - Role of habitat degradation in determining fish distribution and abundance along the lowland Warta River, Poland. $J$. Appl. Ichthyol., 23, 9-18.

Kruk A. \& Penczak T. 2003. - Impoundment impact on populations of facultative riverine fish. Ann. Limnol. - Int. J. Lim., 39, 197-210.

Kruk A., Penczak T., Galicka W., Koszaliński H., Tłoczek K., Kostrzewa J. \& Marszał L. 2000. - Fish fauna of the Warta River. Sci. Ann. Pol. Angl. Assoc., 13, 35-67 (in Polish with Engl. summ.).

Kruk A., Penczak T. \& Przybylski M. 2001. - Long term changes in the fish fauna of the upper Warta River. Sci. Ann. Pol. Angl. Assoc., 14/Suppl., 189-211 (in Polish with Engl. summ.).

Kruk A., Szymczak M. \& Spychalski P. 2003. - Ichthyofauna of the City of Łódź. Part I. Systems of the Jasień and Łódka Streams. Sci. Ann. Pol. Angl. Assoc., 16, 79-96 (in Polish with Engl. summ.).

Kruk A., Spychalski P. \& Galicka W. 2005. - Ichthyofauna of the City of Łódź. Part II. System of the Sokołówka Stream. Sci. Ann. Pol. Angl. Assoc., 18, 29-46 (in Polish with Engl. summ.).

Kruk A., Penczak T., Zięba G., Koszaliński H., Marszał L., Tybulczuk S. \& Galicka W. 2006. - Fish fauna of the Widawka River system. Part I. Widawka. Sci. Ann. Pol. Angl. Assoc., 19, 85-101 (in Polish with Engl. summ.).

Kruk A., Lek S., Park Y.S. \& Penczak T. 2007. - Fish assemblages in the large lowland Narew River system (Poland): application of the self-organizing map algorithm. Ecol. Modell., 203, 45-61.
Kubečka J. \& Vostradovský J. 1995. - Effects of dams, regulation and pollution on fish stocks in the Vltava River in Prague. Regul. Rivers: Res. Mgmt, 10, 93-98.

Kukuła K. 2003. - Ichthyofauna of a mountain river upstream from a big dam reservoir (the upper San River, South-eastern Poland). Arch. Hydrobiol., 157, 413-431.

Kulmatycki W. 1936. - Hydrografia i rybostan rzek województwa łódzkiego [Hydrography and ichthyofauna of rivers in the Łódź Voivodeship]. Czas. Przyr. Ilustr., 109, 123-150.

Lamouroux N., Capra H., Pouilly M. \& Souchon Y. 1999. - Fish habitat preferences in large streams of southern France. Freshwater Biology, 42, 673-687.

Lek S. \& Guegan J. F. 1999. - Artificial neural networks as a tool in ecological modelling, an introduction. Ecol. Modell., 120, 65-73.

Lek S. \& Guegan J.F., eds 2000. - Artificial neuronal networks: application to ecology and evolution. Springer, Berlin.

Lek S., Scardi M., Verdonschot P.F.M., Descy J.P. \& Park Y.S., eds 2005. - Modelling community structure in freshwater ecosystems. Springer, Berlin.

Ligon F.K., Dietrich W.E. \& Trush W.J. 1995. - Downstream ecological effects of dams. BioScience, 45, 183-192.

Marszał L. \& Przybylski M. 1996. - Threatened and rare fish species in Central Poland. In Witkowski A. \& Heese T. (eds). Protection of rare and endangered fish species in Poland - current state and perspectives. Zoologica Poloniae 41/Suppl., 61-72 (in Polish with English summ.).

Mastrorillo S. \& Dauba F. 1999. - Short-term impact of reservoir cleaning on the microhabitat use of three non-salmonid fishes in a piedmont river in south west France. Aquat. Sci., 61, 323-336.

Mastyński J. 1992. - Ichtiofauna środkowego biegu Warty i jej zmiany wywołane zanieczyszczeniami w latach 1960-1990 [The ichthyofauna in the middle course of the Warta River and its changes caused by pollution in 1960-1990]. Wyd. UAM, Poznań, Seria Biologia, 49, 209-220 (in Polish).

Matthews W.J. \& Marsh-Matthews E. 2003. - Effects of drought and fish across axes of space, time and ecological complexity. Freshwater Biology, 48, 1232-1253.

Nilsson C., Reidy C.A., Dynesius M. \& Revenga C. 2005. - Fragmentation and flow regulation of the world's large river systems. Science, 308, 405-408.

Nowak M. \& Zalewski M. 1991. - The fish distribution in habitats of lowland river Grabia. Acta Univ. Lodz., Folia limnol., 5, 153-165.

Oberdorff T., Pont D., Hugueny B. \& Chessel D. 2001. - A probabilistic model characterizing fish assemblages of French rivers: a framework for environmental assessment. Freshw. Biol., 46, 399-417.

Odum E.P. 1980. - Ecology. Holz-Saunders, London, p. 244.

Park Y.S., Céréghino R., Compin A. \& Lek S. 2003a. - Applications of artificial neural networks for patterning and predicting aquatic insect species richness in running waters. Ecol. Modell., 160, 265-280.

Park Y.S., Chang J., Lek S., Cao W. \& Brosse S. 2003b. - Conservation strategies for endemic fish species threatened by the Three Gorges Dam. Conservation Biology, 17, 1748-1758.

Pawłowski L.K. 1958. - Wrotki (Rotatoria) rzeki Grabi [Rotifers (Rotatoria) of the Grabia River]. Societas Scientiarum Lodziensis, Sectio III, Łódź (in Polish with French and Russian summ.).

Penczak T. 1967. - The biological and technical principles of the fishing by use of direct-current field. Przegl. Zool., 11, 114-131 (in Polish with Engl. summ.).

Penczak T. 1969. - The ichthyofauna of the rivers of the Łódź Upland and adjacent areas. Part I c. The hydrography and fishes of the Warta basin. Acta Hydrobiol., 11, 69-118 (in Polish with Engl. summ.). 
Penczak T. 2001. - Populations of fish in relation to riparian ecotone development in the Narew river catchment. Ecohydrology \& Hydrobiology, 1/1-2, 163-176.

Penczak T. \& Jakubowski H. 1990. - Drawbacks of electric fishing in rivers. Pages 115-122 in Cowx I.G. (ed.). Developments in electric fishing. Fishing News Books, Oxford.

Penczak T. \& Kruk A. 2000. - Threatened obligatory riverine fishes in human-modified Polish rivers. Ecol. Freshw. Fish, 9, 109-117.

Penczak T. \& Kruk A. 2005. - Patternizing of impoundment impact (1985-2002) on fish assemblages in a lowland river using the Kohonen algorithm. J. Appl. Ichthyol., 21, 169-177.

Penczak T., Głowacki Ł., Galicka W. \& Koszaliński H. 1998a. A long-term study (1985-1995) of fish populations in the impounded Warta River, Poland. Hydrobiologia, 368, 157-173.

Penczak T., Kruk A., Koszaliński H., Marszał L. \& Kostrzewa J. 1998b. - Monitoring of fish fauna in the Gwda drainage basin. Sci. Ann. Pol. Angl. Assoc., 11, 5-28 (in Polish with Engl. summ.).

Penczak T., Kostrzewa J., Marszał L., Koszaliński H. \& Kruk A. 1999. - Fish fauna of the Noteć River. Sci. Ann. Pol. Angl. Assoc., 12, 81-94 (in Polish with Engl. summ.).

Penczak T., Kruk A., Koszaliński H., Kostrzewa J., Marszał L., Galicka W. \& Głowacki Ł. 2000. - Fishes of three oxbow lakes and their parent Pilica River: 25 years later. Pol.Arch. Hydrobiol., $1,115-130$.

Penczak T., Głowacki Ł., Kostrzewa J., Kruk A., Koszaliński H., Galicka W., Marszał L. \& Zięba G. 2003a. - Influence of climaterelated temporal changes on fish assemblages in oxbow lakes and in their parent Pilica River (continuation). Ecohydrology \& Hydrobiology, 3, 71-85.

Penczak T., Zięba G., Koszaliński H. \& Kruk A. 2003b. - The importance of oxbow lakes for fish recruitment in a river system. Arch. Hydrobiol., 158, 267-281.

Penczak T., Kruk A., Park Y.S. \& Lek S. 2005. - Patterning spatial variations in fish assemblage structures and diversity in the Pilica River system. Pages 100-113 in Lek S., Scardi M., Verdonschot P.F.M., Descy J.P. \& Park Y.S. (eds). Modelling community structure in freshwater ecosystems. Springer, Berlin.

Penczak T., Kruk A., Grzybkowska M. \& Dukowska M. 2006. Patterning of impoundment impact on chironomid assemblages and their environment with use of the self-organizing map (SOM). Acta Oecologica, 30, 312-321.

Petts G.E. 1984. - Impounded Rivers. John Wiley \& Sons, Chichester.

Prowse T.D. 2001. - River-Ice Ecology. II: Biological Aspects. Journal of Cold Regions Engineering, 15, 17-33

Przybylski M. 1993. - Longitudinal pattern in fish assemblages in the upper Warta River, Poland. Arch. Hydrobiol., 126, 499-512.

Przybylski M. 1996. - Variation in fish growth characteristics along a river course. Hydrobiologia, 325, 39-46.

Przybylski M. \& Bańbura J. 1989. - Feeding relations between the gudgeon (Gobio gobio (L.)) and the stone loach (Noemacheilus barbatulus (L.)). Acta Hydrobiol., 31, 109-119.

Przybylski M., Frankiewicz P. \& Bańbura J. 1993. - The fish fauna of the upper Warta River drainage basin. Sci. Ann. Pol. Angl. Assoc., 6, 49-78 (in Polish with Engl. summ.).

Przybylski M., Boron A. \& Kruk A. 2004. - Growth of barbel, Barbus barbus (L.) in the upper Warta River, Odra River system. Ecohydrology \& Hydrobiology, 2, 183-190.
Pygott J.R., O’Hara K. \& Eaton J.W. 1990. - Fish community structure and management in navigated British canals. Pages 547-557 in van Densen W.L.T., Steinmetz B. \& Hughes R.H. (eds). Management of freshwater fisheries. Pudoc, Wageningen.

Quinn G.P. \& Keough M.J. 2002. - Experimental Design and Data Analysis for Biologists. Cambridge University Press, Cambridge.

Schiemer F. \& Wieser W. 1992. - Epilogue: food and feeding ecomorphology, energy assimilation and conversion in cyprinids Env. Biol. Fish., 33, 223-227.

Siligato S. \& Böhmer J. 2001. - Using indicators of fish health at multiple levels of biological organization to assess effects of stream pollution in southwest Germany. Journal of Aquatic Ecosystem Stress and Recovery, 8, 371-386.

Slavík O. \& Bartoš L. 2001. - Spatial distribution and temporal variance of fish communities in the channelized and regulated Vltava River (Central Europe). Environmental Biology of Fishes, 61, 47-55.

Verneaux J. 1981. - Les poissons et la qualite' des cours d'eau. Annales Scientifiques de l'Universite de Franche-Comte, 2, 33-41.

Wachowiak G. 2005. - Rozwój zespołu górniczo-energetycznego "Bełchatów" na tle lokalizacji posterunków wodowskazowych Działu Służby Obserwacyjno-Pomiarowej Oddziału IMGW w Poznaniu [Development of the Bełchatów mining-energetic complex versus the location of water level gauge stations of the Observation and Measurement Service Department of the IMGW Division in Poznań]. Gazeta Obserwatora IMGW, 5, 9-12 (in Polish).

Wang L., Lyons J., Kanehl P. \& Bannerman R. 2001. - Impacts of urbanization on stream habitat and fish across multiple spatial scales. Environmental Management, 2, 255-266.

Welton J.S., Mills C.A. \& Pygott J.R. 1991. - The effect of interaction between the stone loach Noemacheilus barbatulus (L.) and the bullhead Cottus gobio (L.) on prey and habitat selection. Hydrobiologia, 220, 1-7.

Wiśniewolski W. 1987. - Commercial catches of fishes in the Vistula, Odra and Warta Rivers in 1953-1978 years. Rocz. Nauk Rol., 101, 71-114 (in Polish with Engl. and Russian summ.).

Witkowski A. 1986. - Structure of communities and biomass of ichthyofauna in the Biebrza River, its old river beds and affluents. Polish Ecological Studies, 10, 447-474.

Witkowski A., Błachuta J. \& Kusznierz J. 1991. - Ichthyofauna of the Widawa River drainage basin after regulation. Sci. Ann. Pol. Angl. Assoc., 4, 25-46 (in Polish with Engl. and Russian summ.).

Witkowski A., Błachuta J., Kusznierz J. \& Kołacz M. 1992.Ichthyofauna of the Ślęża and Oława Rivers and their tributaries. Sci. Ann. Pol. Angl. Assoc., 5, 137-154 (in Polish with Engl. and Russian summ.).

Wolter C. 2001. - Rapid changes of fish assemblages in artificial lowland waterways. Limnologica, 31, 27-35.

Wolter C. \& Vilcinskas A. 1997. - Perch (Perca fluviatilis) as an indicator species for structural degradation in regulated rivers and canals in the lowlands of Germany. Ecol. Freshw. Fish, 6, 174-181.

Zalewski M., Frankiewicz P., Przybylski M., Bańbura J. \& Nowak M. 1990. - Structure and dynamics of fish communities in temperate rivers in relation to the abiotic-biotic regulatory continuum concept. Pol. Arch. Hydrobiol., 37, 151-176.

Zalewski M., Frankiewicz P. \& Nowak M. 1995. - Biomanipulation by ecotone management in a lowland reservoir. Hydrobiologia, $303,49-60$. 
APPENDIX: Fish species recorded in the Widawka and Grabia Rivers in 1963-66 and 2002-04. Reproductive guilds according to Balon (1990). Rheophilic species are marked with an asterisk, $\mathrm{s}-$ species recorded sporadically (at $<5$ sites of any sampling period).

\section{Nonguarding and open substratum egg scattering (A.1)}

Pelagophil (A.1.1.)

Lithopelagophil (A.1.2)

Lithophils (A.1.3)

Phytolithophils (A.1.4)

Phytophils (A.1.5)

Psammophils (A.1.6)

Lithophils (A.2.3)

Ostracophil (A.2.4)

Phytophil (B.1.4)

Ariadnophil (B.2.4)

Speleophil (B.2.7)
Anguilla anguilla (L.)

Lota lota (L.)

Vimba vimba (L.)

Alburnoides bipunctatus (Bloch)

Aspius aspius (L.)

Chondrostoma nasus (L.)

Barbus barbus (L.)

Leuciscus cephalus (L.)

Leuciscus leuciscus (L.)

Leuciscus idus (L.)

Rutilus rutilus (L.)

Alburnus alburnus (L.)

Abramis brama (L.)

Blicca bjoerkna (L.)

Perca fluviatilis $\mathrm{L}$.

Gymnocephalus cernuus (L.)

Esox lucius L.

Scardinius erythrophthalmus (L.)

Tinca tinca (L.)

Cyprinus carpio $\mathrm{L}$.

Carassius gibelio (Bloch)

Cobitis sp.

Barbatula barbatula (L.)

Gobio gobio (L.)

Nonguarding and brood hiding (A.2)

Salmo trutta trutta $\mathrm{m}$. fario L.

Salmo trutta trutta m. trutta $\mathrm{L}$.

Thymalus thymalus (L.)

Rhodeus sericeus (Bloch)

Guarding and clutch tending (B.1)

Leucaspius delineatus (Heckel)

sunbleak $^{\mathrm{s}}$

Guarding and nesting (B.2)

Gasterosteus aculeatus L.

Ameiurus nebulosus (LeSueur) eel

burbot*

vimba*

spirlin*s $^{*}$

asp*s

nase*

barbel*

chub*

dace*

ide

roach

bleak

bream

silver bream

perch

ruffe

pike

rudd ${ }^{\mathrm{s}}$

tench

carp $^{\mathrm{s}}$

giebel

spined loach

stone loach*

gudgeon*

brown trout*

sea trout*s

grayling*s

bitterling ${ }^{s}$

stickleback ${ }^{\mathrm{s}}$

brown bullhead 